\title{
ANAlysis of Temperature Data In THE AREA OF THE City OF SARAJEVo (BJELAVE) IN PERIOD From 2000-2010
}

\author{
Ismira Ahmovic, Ejub Dzaferovic \& Halima Hadziahmetovic
}
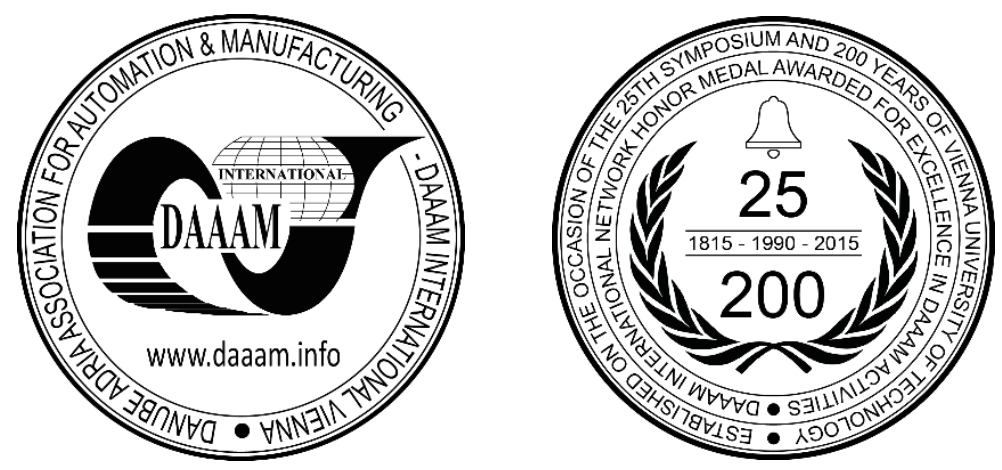

This Publication has to be referred as: Ahmovic, I[smira]; Dzaferovic, E[jub] \& Hadziahmetovic, H[alima] (2018). Analysis of Temperature Data in the Area of the City of Sarajevo (Bjelave) in Period From 2000-2010, Proceedings of the 29th DAAAM International Symposium, pp.0260-0266, B. Katalinic (Ed.), Published by DAAAM International, ISBN 978-3-902734-20-4, ISSN 1726-9679, Vienna, Austria

DOI: $10.2507 / 29$ th.daaam.proceedings.037

\begin{abstract}
In this paper was made a statistical analysis of the air temperature at the meteorological station in Sarajevo (Bjelave) in the period from 2000 to 2010 . The method used for statistical analysis is the factorial experiment with two factors. The data used during this research were obtained from the Federal Hydrometeorological Institute of Bosnia and Herzegovina. After analysis and processing data of air temperatures are given the cumulative values of mean air temperatures by years and months for the area of Sarajevo.
\end{abstract}

Keywords: climate change; temperature; rainfall; factorial experiment; analysis of variance

\section{Introduction}

Climate change is a long-term change in the statistical distribution of climatic factors over a period of ten to one million years. This can be a change in the average climatic elements or a change in the distribution of climate events with respect to the average values, or the occurrence of more extreme weather events. Climate change, caused by elevated temperatures, atmospheric precipitation, is expected to lead to a number of problems that will have an impact on the development of society. The damage that will occur due to natural disasters, but also those that already occur, have a negative impact on the development of society and human health [8].

In order to succeed in these efforts, big adjustments will have to be made, because, even if immediate efforts to reduce emissions are to begin, climate change will significantly affect the poorest countries.

According to the reports of the Intergovernmental Panel on Climate Change (IPCC), the largest warming in Europe is in the Russian Federation and the Iberian peninsula and the least along the Atlantic Ocean. Temperatures are the highest in winter and follow the global trend. During the summer, southern Europe is getting hotter than the northern one. The third climate assessment of the IPCC indicates that during the 1990-2100 period, the mean global temperature of the surface layers of the atmosphere will increase by $1,4-5,8^{\circ} \mathrm{C}$ [6]. When assessing the vulnerability of Bosnia and Herzegovina to climate change, it is necessary to understand the current climatic conditions in the country, as well as forecasts for the future under different climate change scenarios. 
Climate is directly related to social development and the way in which society develops, but on the other hand, it has been proven that the development of society and the excessive consumption of natural resources and excessive pollution caused directly influenced the climate change. Three climate characteristics and climate change can affect social development [9], [10]:

- the temperature that is on the rise,

- the amount of precipitation that is decreasing,

- extreme weather events, such as storms, heat shocks and droughts, intense precipitation that have been more pronounced, more frequent and more intense in recent years.

Temperature also affects human health and economic development. Average temperatures and precipitation are crucial for several economic sectors in Bosnia and Herzegovina. For example, existing climatic conditions, such as sufficient precipitation, allow the cultivation of different crops - often without irrigation. The climate also determines the duration of the tourist season, primarily winter sports, which has a great tradition in Bosnia and Herzegovina and has attracted an increasing number of investments lately. Climate change will also have a major impact on the electricity sector of Bosnia and Herzegovina, where a significant amount of electricity is produced using hydro-potential (around 40\%). In addition, it is important to mention the sectors of agriculture, water supply, fisheries, as well as the consequences that are related to human health (e.g. thermal shock), but also the consequences for natural resources (e.g. fires) [7].

Based on temperature characteristics, the territory of Bosnia and Herzegovina can be divided into three temperature zones: warm, moderate and cold. The warm zone includes the Adriatic coast and the lower parts of Herzegovina. In the lowlands of Herzegovina, summer is hot, while winters are very mild. The average winter temperatures are above $5^{\circ} \mathrm{C}$, while the summer temperatures reach up to $40^{\circ} \mathrm{C}$ (Mostar, Trebinje, Capljina). Mean annual temperatures have a value above $12^{\circ} \mathrm{C}$. Moderate areas include flatland and hilly regions in the central part of Bosnia and Herzegovina. The summers are warm and winters are moderately cold. The average winter temperatures are around $0^{\circ} \mathrm{C}$, and the summer temperatures reach $35^{\circ} \mathrm{C}$ (Banja Luka, Bijeljina, Sarajevo, Tuzla). The average annual temperatures range from $10^{\circ} \mathrm{C}$ to $12^{\circ} \mathrm{C}$, while in areas above $500 \mathrm{~m}$ below $10^{\circ} \mathrm{C}$. Cold regions are mountainous areas, where the summers of brightly (days of moderately warm and night cool), while winters are very cold). During the last three months of the year, these regions have a mean temperature lower than $0^{\circ} \mathrm{C}$ (Bjelašnica, Sokolac, Kupres) (Fig. 1.) [5].

From this analysis it can be established that in the territory of Bosnia and Herzegovina there is a rise in the temperature of the air, which is related to increasing the concentration of greenhouse gases in the Earth's atmosphere. A major problem in the area of the city of Sarajevo is that during the winter period there is an increase in the concentration of harmful gases in the atmosphere (primarily $\mathrm{CO}_{2}$ ), as a result of the intensive use of fossil fuels [1].

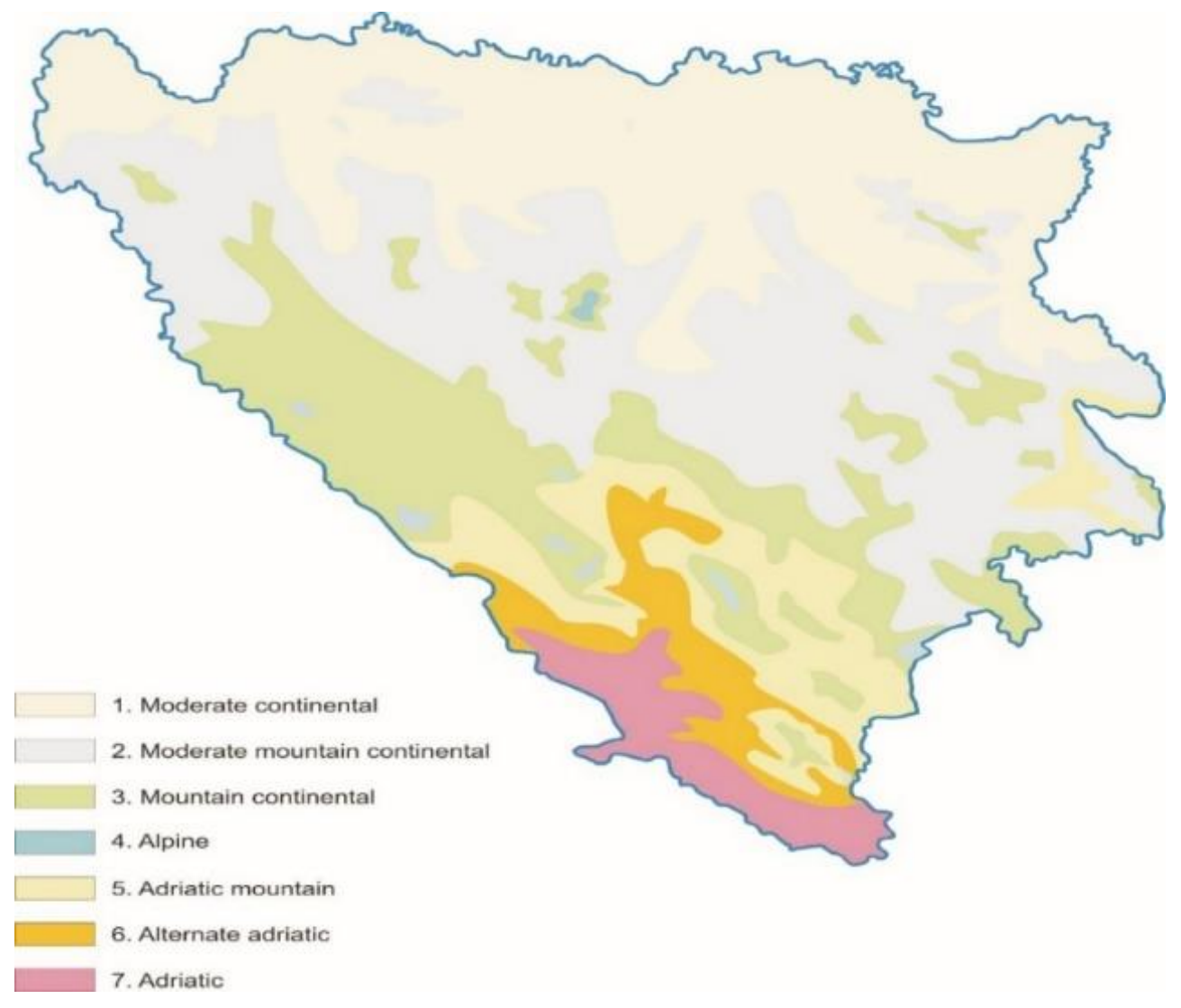

Fig. 1. Climate distribution [5] 
The aim of this research is to obtain a trend of air temperature trends in the area of Sarajevo (Bjelava) for the period from 2000 to 2010, which could be compared and with the trend of air temperature trends for the period from 1961 to 1990 (which according to the World Meteorological

Organization is standard for all meteorological analyses) using a method of statistical analysis is a factorial experiment with two factors. These results could also be used in other areas, such as: construction, agriculture, energy, transport and medicine.

\section{Mean monthly air temperatures at the meteorological station Sarajevo (Bjelave)}

In table 1 are given mean monthly air temperatures at the meteorological station Sarajevo (Bjelave) for the period 20002010 .

\begin{tabular}{|c|c|}
\hline \multirow{2}{*}{ Months } & Monthly air temperatures at the meteorological station Sarajevo (Bjelave) \\
& {$\left[{ }^{\circ} \mathrm{C}\right]$} \\
\hline January & 0,0 \\
\hline February & 1,6 \\
\hline March & 5,8 \\
\hline April & 10,5 \\
\hline May & 15,3 \\
\hline June & 18,5 \\
\hline July & 20,4 \\
\hline August & 20,3 \\
\hline September & 14,7 \\
\hline October & 11,1 \\
\hline November & 6,5 \\
\hline December & 1,1 \\
\hline
\end{tabular}

Table 1. Mean monthly air temperatures at meteorological station Sarajevo (Bjelave) for the period from 2000 to 2010 [5]

\section{Research methods}

For the study, a statistical analysis was used for the factorial experiment with two factors, which will cover the period from 2000-2010. years. Statistical analysis the factorial experiment involves only two factors, for example, A and B, the first factor being years (a-levels), and the second factor being months (b-levels) [4].

\subsection{Factorial experiment}

Statistical methods are used to describe and understand the variability. By the notion of variability, it is assumed that successful observation of a system or phenomenon does not always give an exact result.

In this paper we use a factorial experiment with two factors (A and B). Under the factorial experiment, it is assumed that in every complete attempt or repetition of the experiment, all possible combinations of factor levels are investigated. Therefore, if the experiment contains two factors A and B, with a of levels of factor A and b of levels of factor B, each performance experiment contains all ab combination treatments.

The influence of a given factor is defined as a change in reaction, caused by a change in the level. This is called the main effect because it refers to the primary (main) factors in the study [2], [3].

\subsection{Two- Factor Factorial Experiment}

The simplest example of a factor experiment involves only two factors, e.g. factor A and factor B. We have a of levels of factor $\mathrm{A}$ and $\mathrm{b}$ of level of factor B. Table 2 shows a two -factor experiment. The experiment contains $\mathrm{n}$ repetitions, and each repetition contains all ab combination treatments. 


\begin{tabular}{|c|c|c|c|c|c|c|c|}
\hline & & \multicolumn{4}{|l|}{ Factor B } & \multirow[b]{2}{*}{ Total } & \multirow[b]{2}{*}{ Mean } \\
\hline & & 1 & 2 & $\ldots$ & $\mathrm{b}$ & & \\
\hline \multirow[t]{4}{*}{ Factor A } & 1 & $\begin{array}{l}\mathrm{y}_{111}, \mathrm{y}_{112}, \\
\ldots, \mathrm{y}_{11 \mathrm{n}}\end{array}$ & $\begin{array}{l}\mathrm{y}_{121}, \mathrm{y}_{122}, \\
\ldots, \mathrm{y}_{12 \mathrm{n}}\end{array}$ & & $\begin{array}{l}\mathrm{y}_{1 \mathrm{~b} 1}, \mathrm{y}_{1 \mathrm{~b} 2}, \\
\ldots, \mathrm{y}_{1 \mathrm{bn}}\end{array}$ & $\mathrm{y}_{1} .$. & $\bar{y}_{1}$. \\
\hline & 2 & $\begin{array}{l}\mathrm{y}_{211}, \mathrm{y}_{212}, \\
\ldots, \mathrm{y}_{21 \mathrm{n}}\end{array}$ & $\begin{array}{l}\mathrm{y}_{221}, \mathrm{y}_{222}, \\
\ldots, \mathrm{y}_{22 \mathrm{n}}\end{array}$ & & $\begin{array}{l}\mathrm{y}_{2 \mathrm{~b} 1}, \mathrm{y}_{2 \mathrm{~b} 2}, \\
\ldots, \mathrm{y}_{2 \mathrm{bn}}\end{array}$ & $\mathrm{y}_{2} .$. & $\bar{y}_{2}$. \\
\hline & $\vdots$ & & & & & & \\
\hline & $\mathrm{a}$ & $\begin{array}{l}\mathrm{y}_{\mathrm{a} 11}, \mathrm{y}_{\mathrm{a} 12}, \\
\ldots, \mathrm{y}_{\mathrm{a} 1 \mathrm{n}}\end{array}$ & $\begin{array}{l}\mathrm{y}_{\mathrm{a} 21}, \mathrm{y}_{\mathrm{a} 22}, \\
\ldots, \mathrm{y}_{\mathrm{a} 2 \mathrm{n}}\end{array}$ & & $\begin{array}{l}\mathrm{y}_{\mathrm{ab} 1}, \mathrm{y}_{\mathrm{ab} 2}, \\
\ldots, \mathrm{y}_{\mathrm{abn}}\end{array}$ & $\mathrm{y}_{\mathrm{a} . .}$ & $\bar{y}_{a} \cdot$ \\
\hline $\begin{array}{l}\text { Total } \\
\text { mean }\end{array}$ & & $\frac{\mathrm{y}_{.1} .}{\mathrm{y}_{.1 .}}$ & $\frac{\mathrm{y}_{.2 .}}{\bar{y}_{.2 .}}$ & & $\begin{array}{l}\mathrm{y}_{. \mathrm{b} .} \\
\overline{\mathrm{y}}_{\text {.b. }}\end{array}$ & $\mathrm{y} \ldots$ & $\bar{y}$ \\
\hline
\end{tabular}

Table 2. Data distribution for a two -factor factorial experiment [2], [3]

$$
y_{i j k}=\mu+\tau_{i}+\beta_{j}+(\tau \beta)_{i j}+\epsilon_{i j k}\left\{\begin{array}{l}
i=1,2, \ldots, a \\
j=1,2, \ldots, b \\
k=1,2, \ldots, n
\end{array},\right.
$$

where $\mu$ is the total mean effect, $\tau_{i}$ is the effect of the ith level of factor $A, \beta_{j}$ is the effect of the jth level of factor B, $(\tau \beta)_{i j}$ is the effect of interaction between $\mathrm{A}$ and $\mathrm{B}$ and $\epsilon_{\mathrm{ijk}}$ is a random error that has a normal distribution with mean value 0 and variance $\sigma^{2}$.

Interest is placed on the hypothesis testing without major effect for factor A, without major effect for factor B, and without the effect of AB interaction. Since there are only two factors in the experiment, the test procedure is sometimes called a two-way variance analysis [2], [3].

Statistical analysis the factorial experiment involves only two factors, say A and B, one factor being years (a-level), and the second factor is the months (b-level). Table 3 is given the analysis of variance (ANOVA).

\begin{tabular}{|c|c|c|c|c|}
\hline Source of variation & Sum of squares & Degrees of freedom & Mean value & Fo \\
\hline A treatments & $\mathrm{SS}_{\mathrm{A}}$ & $(\mathrm{a}-1)$ & $\mathrm{MS}_{\mathrm{A}}=\frac{\mathrm{SS}_{\mathrm{A}}}{\mathrm{a}-1}$ & $\frac{\mathrm{MS}_{\mathrm{A}}}{\mathrm{MS}_{\mathrm{E}}}$ \\
\hline $\mathrm{B}$ treatments & $\mathrm{SS}_{\mathrm{B}}$ & $(\mathrm{b}-1)$ & $\mathrm{MS}_{\mathrm{B}}=\frac{\mathrm{SS}_{\mathrm{B}}}{\mathrm{b}-1}$ & $\frac{\mathrm{MS}_{\mathrm{B}}}{\mathrm{MS}_{\mathrm{E}}}$ \\
\hline Interaction & $\mathrm{SS}_{\mathrm{AB}}$ & $(\mathrm{a}-1)(\mathrm{b}-1)$ & $\mathrm{MS}_{\mathrm{AB}}=\frac{\mathrm{SS}_{\mathrm{AB}}}{(\mathrm{a}-1)(\mathrm{b}-1)}$ & $\frac{\mathrm{MS}_{\mathrm{AB}}}{\mathrm{MS}_{\mathrm{E}}}$ \\
\hline Error & $\mathrm{SS}_{\mathrm{E}}$ & $\mathrm{ab}(\mathrm{n}-1)$ & $\mathrm{MS}_{\mathrm{E}}=\frac{\mathrm{SS}_{\mathrm{E}}}{\mathrm{ab}(\mathrm{n}-1)}$ & \\
\hline Total & $\mathrm{SS}_{\mathrm{T}}$ & $(\mathrm{abn}-1)$ & & \\
\hline
\end{tabular}

Table 3. The analysis of variance for the two-factor factorial (ANOVA table), Fixed-effects model [2], [3]

\section{Analysis of the results}

In table 4 are given the results of the statistical analysis of the two-factor factorial experimental, which were made in a computer program in $\mathrm{C}++$ language for linear regression for the Sarajevo meteorological station (Bjelave) for the period 2000-2010 [1]. 


\begin{tabular}{|c|c|c|c|c|c|}
\hline Source of variation & Sum of square & Degrees of freedom & Mean value & $\mathbf{F}_{\mathbf{0}}$ & $\mathbf{F}_{\mathbf{t}}$ \\
\hline A treatments & 137,230 & 9 & 15,248 & 1,538 & 1,92 \\
\hline B treatments & 18008,318 & 11 & 1637,120 & 165,087 & 1,81 \\
\hline Interaction & 1018,107 & 99 & 10,284 & 1,037 & 1,31 \\
\hline Error & 2380,013 & 240 & 9,917 & & \\
\hline Total & 21543,668 & 359 & & & \\
\hline
\end{tabular}

Table 4. The analysis of variance for the two-factor factorial (ANOVA table), Meteorological station Sarajevo (Bjelave) (temperature for the period 2000.-2010) [1]

In the two-factor factorial (ANOVA table) was taken a $=10$ levels of factor A, depending on the number of years of the given time interval (somewhere 8 , and somewhere 7 , where no data was available). Factor B was taken $b=12$ months per year. Because of the large number of data, the mean values of the decade in the month $n=3$ were taken, thus reducing the fluctuations. These values are considered as repetitions and thus an error in experimental design was determined and the ability to estimate the statistical significance of factors A and B (years and months). For factor A, it is always 36 (number of months $b=12$ times the number of repetitions $n=3$ ). Factor $B$ is 30 (number of years $a=10$ and $n=3$ ), or 24 or 21 if there are data for 8 or 7 years.

Based on table 4 for air temperatures at the observed location, it can be seen that the $\mathrm{F}_{\mathrm{o}}$ values by years (factor $\mathrm{A}$ ) less than the corresponding tabular $F_{t}$ values, and it can not be claimed that there is a significant difference in the reliability level of $95 \%$. However, the $F_{o}$ values per months (factor B) are considerably larger than tabular as expected, since the temperature changes are significant over the course of the year [1].

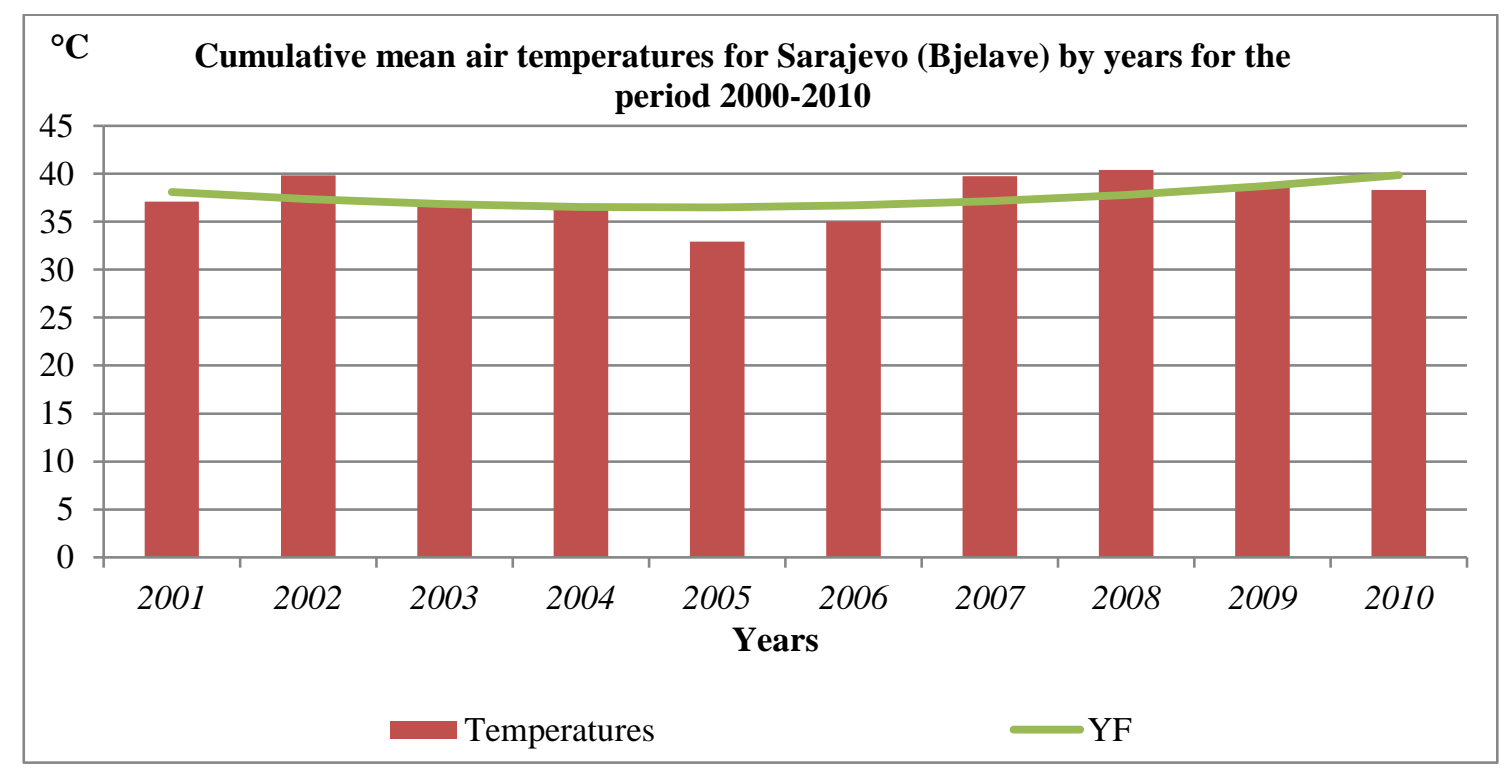

Fig. 2. Cumulative mean air temperatures for Sarajevo (Bjelave) by years for the period 2000-2010 [1]

Figure 2 shows the cumulative mean air temperatures for Sarajevo (Bjelave) by years for the period 2000-2010. The cumulative mean air temperature is $37,1^{\circ} \mathrm{C}$ for 2001. The number of months in one year (the period from 2000 to 2010) in which the measurement was carried out is 12 . For 2002 , the cumulative mean air temperature is $39,83^{\circ} \mathrm{C}$ for Sarajevo (Bjelave), which is higher by $2,73{ }^{\circ} \mathrm{C}$ compared to 2001 . In 2003 , the cumulative mean air temperature is $36,81{ }^{\circ} \mathrm{C}$, and for 2004 is $36,56{ }^{\circ} \mathrm{C}$, if we compare these two values, the difference is small and is $0,25^{\circ} \mathrm{C}$. Already in 2005 , a minimum cumulative mean air temperature of $32,92{ }^{\circ} \mathrm{C}$ is recorded, that can be seen in Figure 2. The reason for the minimum cumulative mean air temperature is the increase in rainy and snowfall during autumn and winter. For 2006, the cumulative mean air temperature is $35,03{ }^{\circ} \mathrm{C}$, but for 2007 is $39,75^{\circ} \mathrm{C}$. In 2008 , the maximum cumulative mean air temperature is recorded at $40,38^{\circ} \mathrm{C}$, that can be seen in Figure 2. The cumulative value of mean air temperature is $38,71{ }^{\circ} \mathrm{C}$ for 2009 , and for 2010 for $38,31^{\circ} \mathrm{C}$ [1].

The year with the minimum cumulative mean air temperature for Sarajevo (Bjelave) in the period from 2000-2010 is $32,92{ }^{\circ} \mathrm{C}$ and recorded in 2005 . While the maximum cumulative mean air temperature is $40,38{ }^{\circ} \mathrm{C}$ and recorded in 2008. For other years of cumulative mean air temperatures have approximately the same value [1]. Figure 3 shows the cumulative mean air temperature for Sarajevo (Bjelave) by months for the period 2000-2010 [1]. 


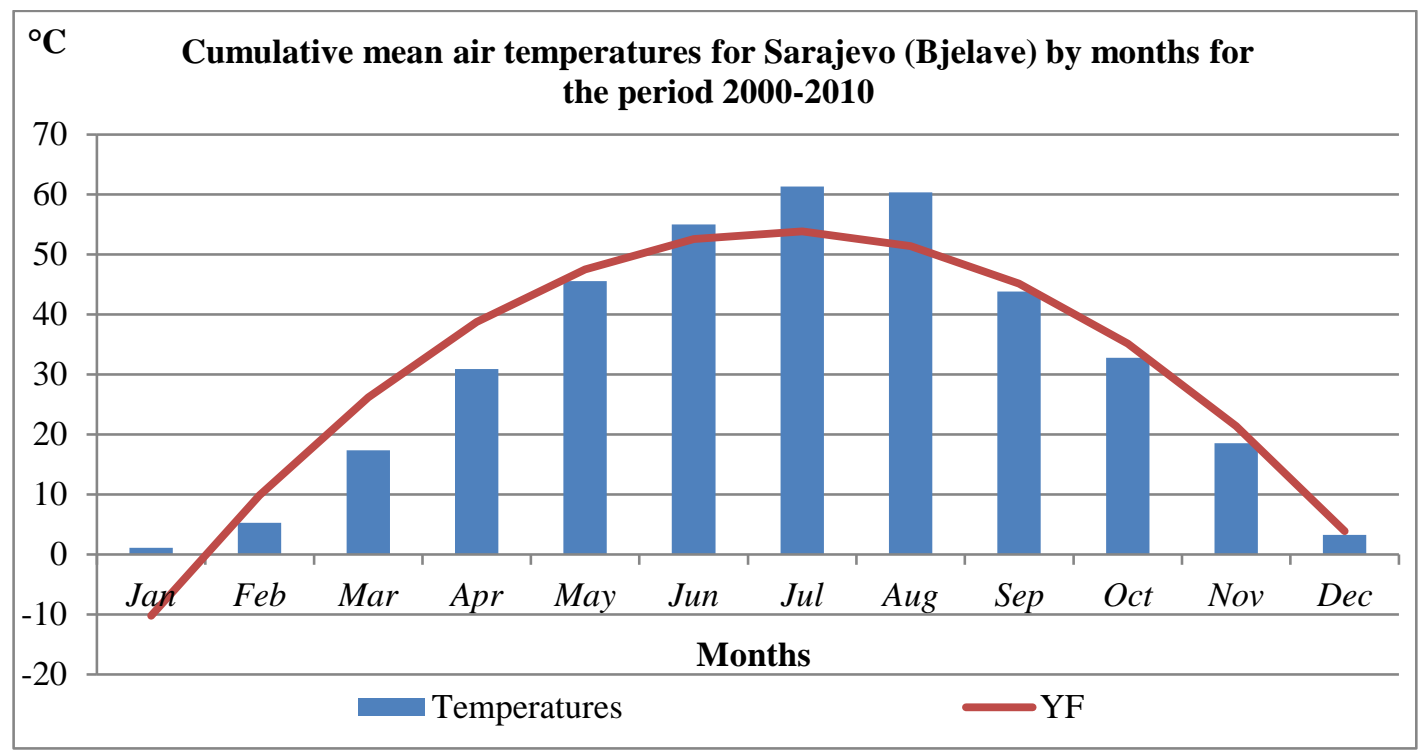

Fig. 3. Cumulative mean air temperatures for Sarajevo (Bjelave) by months for the period 2000-2010 [1]

The cumulative mean air temperature for the month of January for the period from 2000 to 2010 is $-10{ }^{\circ} \mathrm{C}$ for 31 days. In January, the lowest temperatures, the reason is the meteorological occurrences of the greater intensity was especially important for temperature inversions and various forms of fog. For February, the cumulative value of mean air temperature is $5,3{ }^{\circ} \mathrm{C}$ for 28 days. In February, temperature inversion is present, but the intensity is slowly weakening. For the month of March, the cumulative mean air temperature is $17,39^{\circ} \mathrm{C}$ for 31 days. In this month, the cumulative mean air temperature is increasing in relation to the month of February, it is tripled. As for the month of April for the period from 2000 to 2010 , the mean air temperature is $30,93{ }^{\circ} \mathrm{C}$ for 30 days. In May, a gradual thermal transition is gradual from the winter to the summer of the year, so during May, the cumulative mean air temperature is $47,54{ }^{\circ} \mathrm{C}$ for 31 days. For the month of June, the cumulative mean air temperature is $52,58{ }^{\circ} \mathrm{C}$ for 30 days. From the figure 3 , it can be concluded that the cumulative value of the mean air temperature is highest in July and amounts to $61,34^{\circ} \mathrm{C}$ for 31 days. In August, the value of the cumulative mean air temperature is $60,39{ }^{\circ} \mathrm{C}$ for 31 days and decreases by $0,95{ }^{\circ} \mathrm{C}$ compared to July [1].

For the month of September, the cumulative mean air temperature value for Sarajevo (Bjelave) is relatively high 45,14 ${ }^{\circ} \mathrm{C}$ for 30 days. From the figure 3 shows that for the month of September, mean values were decrease, which illustrates the climatic indicator of the passage from the summer period in autumn. In October, there is a significant reduction in the cumulative value of the mean air temperature is $32,80^{\circ} \mathrm{C}$ for 31 days. In that period, there is also a decrease in the illuminated work of the day and a decrease in the decreasing angle of air and at the same time to an increase in the degree of cloudiness and other local meteorological phenomena (fog, etc.). The tendency of a sensible decrease in the cumulative mean air temperature in November continued and there has been a doubled decrease in compared to October. As for the month of December, the cumulative mean air temperature for Sarajevo (Bjelave) is $3,28{ }^{\circ} \mathrm{C}$ for 31 days and on the basis of the processed it can be concluded that this was not the coldest month. During this month, the astronomical and climatological transition from the autumn to the winter part of the year is marked, which can easily be seen from the mean monthly cumulative air temperatures. Also, the date of the winter solstice is falling in December [1].

The month with the minimum cumulative mean air temperature for Sarajevo (Bjelave) in the period from 2000-2010 is January with $-10{ }^{\circ} \mathrm{C}$. While the month with the maximum cumulative air temperature is recorded in July with $61,34{ }^{\circ} \mathrm{C}$. Figure 3 shows that the annual flow of air temperature distribution is evenly distributed throughout the year.

\section{Conclusion}

This paper deals with data obtained from the Federal Hydrometeorological Institute of Bosnia and Herzegovina, which refers to the statistical analysis of air temperature in the area of Sarajevo (Bjelave) for the period 2000-2010.

The method used for statistical analysis is a factorial experiment with two factors. In the two-factor factorial (ANOVA table) was taken $\mathrm{a}=10$ levels of factor $\mathrm{A}$, depending on the number of years of the given time interval (somewhere 8 , and somewhere 7, where no data was available). Factor B was taken $b=12$ months per year. Because of the large number of datas, the mean values of the decade in the month $n=3$ were taken, thus reducing the fluctuations. These values are considered as repetitions and thus an error in experimental design was determined and the ability to estimate the statistical significance of factors A and B (years and months). For factor A, it is always 36 (number of months $b=12$ times the number of repetitions $n=3$ ). Factor $B$ is 30 (number of years $a=10$ and $n=3$ ), or 24 or 21 if there are data for 8 or 7 years. 
Based on the ANOVA table at the observed location, it can be concluded that the $\mathrm{F}_{\mathrm{o}}$ values (factor A) less than the corresponding tabular $F_{t}$ values have been calculated by years, and it can't be claimed that there is a significant difference in the reliability level of $95 \%$. However, the $\mathrm{F}_{\mathrm{o}}$ values per month (factor B) are significantly higher than the tables as expected, as temperature changes are significant over the course of the year.

After analysis and processing of air temperatures are given cumulative values of mean air temperatures by years and months for the area of Sarajevo (Bjelava).

The cumulative mean air temperature for 2001 is $37,1^{\circ} \mathrm{C}$. The number of months in one year (period from 2000 to 2010 ) is 12 . For 2002 , the cumulative value of mean air temperatures for Sarajevo is $39,83{ }^{\circ} \mathrm{C}$, for 2003 is $36,81{ }^{\circ} \mathrm{C}$, for 2004 is $36,56{ }^{\circ} \mathrm{C}$, for 2005 is $32,92^{\circ} \mathrm{C}$, for 2006 is $35,03{ }^{\circ} \mathrm{C}$, for 2007 is $39,75{ }^{\circ} \mathrm{C}$, for 2008 is $40,38{ }^{\circ} \mathrm{C}$, for 2009 is $38,71^{\circ} \mathrm{C}$, while for 2010 is $38,31^{\circ} \mathrm{C}$. The year with the minimum cumulative mean air temperature for Sarajevo (Bjelave) in the period from $2000-2010$ is recorded in 2005 with $32,92{ }^{\circ} \mathrm{C}$. While the maximum cumulative mean air temperature is recorded in 2008 with $40,38^{\circ} \mathrm{C}$.

The cumulative mean air temperature for the month of January is $-10 \mathrm{C}$ for 31 days. For February, the cumulative mean air temperature is $5,3^{\circ} \mathrm{C}$ ( 28 days), for the month of March is $17,39{ }^{\circ} \mathrm{C}$ ( 31 days), for the month of April is $30,93{ }^{\circ}$ $\mathrm{C}$ (30 days), for the month of May is $47,54{ }^{\circ} \mathrm{C}$ ( 31 days), for the month of June is $52,58{ }^{\circ} \mathrm{C}$ ( 30 days), for July is 61,34 ${ }^{\circ} \mathrm{C}$ (31 days), for the month of August is $60,39{ }^{\circ} \mathrm{C}$ (31 days), for the month of September is $45,14{ }^{\circ} \mathrm{C}$ ( 30 days), for the month of October is $32,80{ }^{\circ} \mathrm{C}$ (31 days), for the month of November is $18,52{ }^{\circ} \mathrm{C}$ (30 days), while for the month of December the cumulative mean air temperature for Sarajevo is $3,28{ }^{\circ} \mathrm{C}$ for 31 days. The month with the minimum cumulative mean air temperature for Sarajevo (Bjelave) in the period from 2000-2010 is January with $-10^{\circ} \mathrm{C}$. While the month with the maximum cumulative air temperature is recorded in July with $61,34{ }^{\circ} \mathrm{C}$.

Based on these data, it is important to note that the area of Sarajevo (Bjelave) is on average warmer compared to the lowest parts of the Sarajevo basin. This is primarily a reflection of the specificity of the topographic station of the station, as well as the weaker fog radiation that can occur during the night and during the morning hours in the basin parts of the city, as well as other meteorological phenomena (rainfall, snow depth, wind speed, etc.) A similar way can be the subject of further research.

In the next research, it is necessary to obtain a trend of air temperature movement in the territory of Sarajevo (Bjelava) for the period from 1961 to 1990 , using the method of analysis a factorial experiment with two factors and to compare it with the results obtained for the period from 2000-2010.

\section{Acknowledgements}

This paper is realized in framework of project supported by the Ministry of Education, Science and Youth of Sarajevo Canton.

\section{References}

[1] Ahmović, I. (2014). Climate change and their influence on the water regime in Bosnia and Herzegovina, with special focus on the Sarajevo field, Master thesis, Faculty of Mechanical Engineering Sarajevo, Sarajevo, Bosnia and Herzegovina.

[2] Bajramović, R. (2003). Determination of critical values in normal i t - distribution, Mašinstvo, vol. 2, no. 7, 2003, pp. 93-104.

[3] Demirdžić, I. (1997). Numerical Mathematics, IP Svjetlost, D.D., Zavod za udžbenike i nastavna sredstva, Sarajevo.

[4] Hayter, A.J.(2012). Probability and Statistics for Engineers and Scientists, Brooks/Cole, Boston, USA.

[5] http://www.fhmzbih.gov.ba/. (2018). Accessed on: 2018-10-07.

[6] IPCC (2007). Climate Change 2007: Synthesis Report, Contribution of Working Groups I, II and III to the Fourth Assessment Report of the Intergovernmental Panel on Climate Change [Core Writing Team, Pachauri, R. K., and Reisinger, A. (eds.)], Geneva, Switzerland.

[7] United Nations Development Program in Bosnia and Herzegovina. (2009). The first national report of Bosnia and Herzegovina in accordance with the United Nations Framework Convention on Climate Change, Banja Luka, Bosnia and Herzegovina.

[8] Palandžić, I. (2012). Climate change and water resources in Bosnia and Herzegovina with a special focus on flood protection Master thesis, Faculty of Mechanical Engineering Sarajevo, Sarajevo, Bosnia and Herzegovina.

[9] Toth, T. (2012). Climate change, Zelena lista, Zagreb, http://www. zelenalista.hr/UserFiles/File/brosure/Klimatske_promjene_2012.pdf. Accessed on: 2018-10-07.

[10] Vucijak, B., Midzic Kurtagic, S., Ceric, A., Kupusovic, T. \& Spago, S. (2012). Assessment of Climate Change Effects to Precipitation Patterns using Statistical Process Control Methods, Annals of DAAAM for 2012 \& Proceedings of the 23rd International DAAAM Symposium, Published by DAAAM International, Vienna, pp. 0277 -0280 . 